Research Article

\title{
Sustainable Management of Waste Coconut Shells as Aggregates in Concrete Mixture
}

\author{
Tomas U. Ganiron Jr
}

School of Engineering, Auckland University of Technology, New Zealand

Received 26 June 2013; Accepted 16 December 2013

\begin{abstract}
This study focuses on generating product using agricultural waste as well develop an alternative construction material that will lessen the social and environmental issues. It also paved the way to the recognition of using coconut shells and fiber as substitute for aggregates in developing concrete hollow blocks. This paper presents the result on the workability and compressive strength of concrete containing various percentage of coconut shell content as partial aggregate replacement. Workability test and compressive strength test were conducted in accordance to ASTM C136 and ASTM C137 respectively. Results show that replacement of appropriate coconut shell content able to produce workable concrete with satisfactory strength. Integration of coconut shell enhanced the strength of concrete making it to be the highest as compared to conventional concrete mixture.
\end{abstract}

Keywords: Coconut shells, construction materials, hollow blocks, recycled materials, technical specification

\section{Introduction}

Concern for sustainable development has emerged as one of the major societal issues of the late 20th century. This pertains among others to environmental issues and the conservation of natural resources. The beginnings of this awareness are difficult to pinpoint, but it is clear that it did not originate in the United States, where a public accustomed to an abundance of natural resources was relatively late to realize the limits of these resources and the real costs associated with their wasteful exploitation. But at present, environmental consciousness is being encountered in all walks of life. In the construction industry, increasing attention is being paid to the concept of "green buildings". The search for "green" or environmentally friendly materials in the building industry involves the development of new materials, but might also lead to the reconsideration of traditional ones

The use of coconut by products has been a long time source of income for some people in the country. The coconut has many uses. The fruit itself is used in many industries not only as food but for other uses as well. The energy industry has also seen the potential of the coconut as the coco-diesel was created as an alternative to the fossil fueled oils the Philippines import. Aside from its ornamental use, the shell has been powdered and used as glues and its charcoal form was used as activated carbon and used as filter material for masks and air-conditioning systems. In the construction industry, the husk is used as a mat in preventing the erosion of soils. Boards are created from the husk of the coconut by acquiring the fibers from the husk.

The high cost of construction materials like cement and reinforcement bars, has led to increased cost of construction. This, coupled with the pollution associated with cement production, has necessitated a search for an alternative binder which can be used sorely or in partial replacement of

*E-mail address: tomasuganironjr@gmail.com

ISSN: 1791-2377 @ 2013 Kavala Institute of Technology. All rights reserved. cement in concrete production. More so, disposal of agricultural waste materials such as rice husk, groundnut husk, corn cob and coconut shell have constituted an environmental challenge, hence the need to convert them into useful materials to minimize their negative effect on the environment. Research indicates that most materials that are rich in amorphous silica can be used in partial replacement of cement. It has also been established that amorphous silica found in some pozzolanic materials reacts with lime more readily than those of crystalline form. Use of such pozzolana can lead to increased compressive and flexural strengths .The American Society of Testing Materials (ASTM) defines Pozzolans as siliceous or aluminous materials which possess little or no cementitious properties but will, in the presence of moisture, react with lime $\left[\mathrm{Ca}(\mathrm{OH})_{2}\right]$ at ordinary temperature to form a compound with pozzolanic properties. Recycling of the disposed material is one method of treating the agricultural waste. The used of coconut fiber and coconut shell could be a valuable substitute in the formation of composite material that can be used as a housing construction, such as concrete hollow block [1].

Coconut is famous as multi-function plant that all parts of its plant can be used for various activities [1], [2]. The use of this agricultural waste due to an assumption is that it can replace the existing material used in commercial product in order to reduce cost or improve mechanical proper-ties of the composite material. Industrialists in most of the coconut producing countries hail the economic, environ-mental and technological benefits of utilizing coconut farm wastes [2], [20]. On the farmers' side, agricultural residues can be a source of extra income. Traditionally, coconut farmers dispose the husks, spate, petiole and leaves by burning or allowing these farm wastes to rot in the field [1], [2]. However, worldwide interest in using farm residues for value-added products means that farmers can generate adadditional income aside from amassing environmental dividends. Studies have shown that burning of agricultural wastes causes air pollution, soil erosion and even a decrease 
in soil biological activity that can eventually lead to decreased soil fertility [3] [21]. On the other hand, allowing farm residues to rot in the field may improve the productivity of the soil but the process of decomposition is very slow leading to accumulation of piles of agricultural wastes that can cause phytosanitary problem to the coconut plantation, since decaying debris is ideal breeding place for coconut pest like the rhinoceros beetle [2], [3].

Using agricultural and forest residues for industrial purposes is a much more environment-safe and friendly more than any other method of wastes disposal being commonly adopted nowadays. Research and development in the construction industry are shifting towards exploration of cellulose farm wastes and forest residues processing and production for building materials [3] [22]. The tremendous potential of agricultural and forest residues can be a solution to the problem of inadequate supply and high cost of conventional timbers and dependence from imported building materials. Current research and development efforts in the field of building materials should be supportive of policies of most governments that are aimed in the promotion of import substitution schemes, employment generation and self-reliance [3]. The enormous amount of residues that shall be generated from the farm and forest plantation would then make a stable source of alternative materials for the purpose of building affordable housing units for the majority of the country's population.

Considered the most useful tree in the world, the coconut palm provides food, drink, clothing, shelter, heirloom history, and financial security [3]. Hardly an inch of the coconut palm goes to waste in countries such as the Philippines where families rely on the coconut palm for survival and refer to it as the "tree of life."

The shell, husk, roots of the tree, fronds, flowers, and wood of the trunk are also become useful products. Charcoal filters used in gas masks and cigarettes are made from coconut shells that are burned, leaving pure carbon behind. Charcoal has the ability to trap microscopic particles and impurities and prevent absorption [4]. Charcoal made from coconut shells produces filters of exceptional high performance.

One third of the coconut's make-up is the hairy husk that is soaked in salt water until it is soft enough to spin into rope or twine that is known for its durability [5] [23]. The rope, called coir but pronounced coil, is highly resistant to salt water and does not break down like other fibers including hemp [6]. The coconut husk has household practicality in tropical countries where coconuts are part of almost every cuisine. The husk provides fuel for cooking as well as fiber for making clothing.

Building materials from agricultural and forest wastes are ideal for socialized or low-cost housing since these are generally cheaper than conventional materials [7] [24]. For ex-ample, residues from coconut plantation like husks, fronds and spate can be processed and transformed into excellent stabilized cement-bonded boards or wall panels and corrugated roofing sheets at a much reduced production cost than the conventional cement blocks, galvanized iron sheets, asbestos panels or plywood sheets. Likewise, rice hull/straw, corn stalks, abaca wastes and sugar cane bagasse are locally available materials that can be readily used in manufacturing cement-bonded boards. In addition, indigenous and small diameter trees like "bagalunga" and giant "ipil-ipil" are abundant in coconut plantations particularly in Mindanao, Philippines, either as intercropped or naturally-grown, which can be economically processed into cement-bonded boards [7], [25]. The availability of suitable materials is intimately linked to the development of a new product, such as producing a concrete hollow block using coconut fibers and shells. Generating this product using agricultural waste will introduce alternative construction materials with a low production cost and lessen the social and environmental problems [7], [8]. Modern construction technologies being developed, respond to ecological and social issues of excessive use of raw materials from nature. The main objective of this study will give partial re-placement for the aggregates and will determined the ability and benefits to the concrete hollow block when substitutes [26], [38]. The simple concrete block will continue to evolve as architects and block manufacturers develop new shapes and sizes. These new blocks promise to make building construction faster and less expensive, as well as result in structures that are more durable and energy efficient [8] [27]. Some of the possible block designs for the future include the biaxial block, which has cavities running horizontally as well as vertically to allow access for plumbing and electrical conduits; the stacked siding block, which consists of three sections that form both interior and exterior walls; and the heat soak block, which stores heat to cool the interior rooms in summer and heat them in winter [8] [28].

The researcher made this study to explore the use of coconut shells and fibers as an aggregate. Analyze the performance and the effectiveness of the coconut shells and fibers as aggregates in concrete hollow blocks in terms of physical properties like color, texture, size, and density and by mechanical properties like compressive strength, modulus of elasticity, absorption, thermal conductivity and fire resistance to obtain a design technical specification of concrete hollow blocks [7], [8].

Moreover, this study intends to provide a new point of view about concrete masonry that serves as an assurance with regards to economic crisis. The result of this study will provide and introduce an alternative construction material with a low production cost.

\section{Experimental Investigation}

\subsection{Project Design}

The experimental program covers series of physical property test like sieve analysis, specific gravity, moisture content and mechanical property test such as compressive test were undertaken in accordance with the ASTM [9], [29]. The coconut shell and fiber used in this re-search was taken along Rizal province. As shown in figure 1, the materials gathered were screened discarding foreign materials then placed in a container and sealed to preserved and retain its natural conditions in order to achieve an accurate data for the experiment. As the production starts, the required amounts of sand, coconut shell, fiber and Portland cement are measured to obtain the proper amounts of each material. After the dry materials are blended a small amount of water is added. The concrete is then mixed for six to eight minutes. Once the load of concrete is thoroughly mixed, it is dumped into an inclined bucket conveyor and transported to an elevated hopper [30]. [31]. On top of the block machine at a measured flow rate, the concrete is forced downward into molds. The molds consist of an outer mold box containing several mold liners. The liners determine the outer shape of the block and the inner shape of the block cavities. . When the molds are full, the concrete is compacted by the weight 
of the upper mold head coming down on the mold cavities [10] [32]. Most block machines also use a short burst of mechanical vibration to further aid compaction. The compacted blocks are pushed down and out of the molds onto a flat steel pallet. The pallet and blocks are pushed out of the machine and places them in a curing rack. The blocks are pushed off the steel pallets, and the empty pallets are fed back into a block machine to receive a new set of molded blocks.

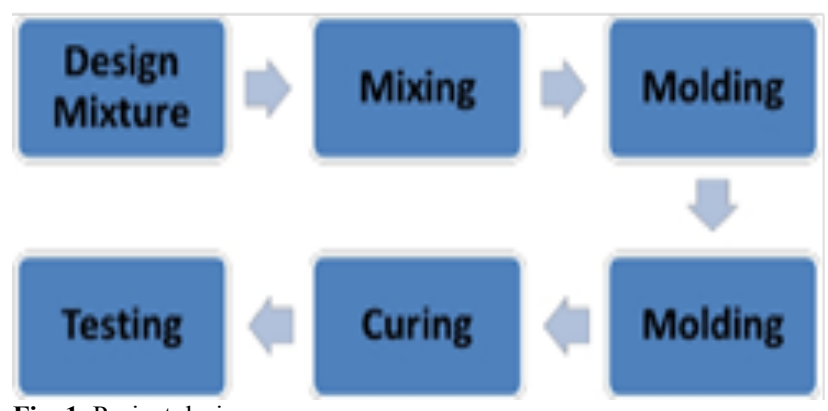

Fig. 1. Project design

\subsection{Project Development}

As shown in figure 3, the researcher develops this experiment through collecting coconut shells and fiber. If gathered materials are wet, it will undergo drying process, or if dry it will be directly screened to discard foreign materials. Shells are crushed and fibers are stripped from coconut husk, after crushing and stripping it will be screened again to discard foreign materials. Physical property is observed through sieve analysis, if it will confirm with the standards [11], [33]. Concrete hollow block sample is done by mixing crushed coconut shell and fiber, sand and cement. Mixture is poured to the machine to form a 4 inches concrete hollow blocks. The next stage is curing the specimen for 7 , 14 and 28 days [11], [12], [39]. On the said dates the specimen will undergo laboratory test such as compressive strength test, moisture content, and absorption.

\section{Results and Discussion}

3.1 Physical Properties of Concrete Hollow Blocks (CHB) Table 1 shows the physical properties of commercial $\mathrm{CHB}$ and CHB with coconut shell and fiber. The color is simply observed through visual inspection. $\mathrm{CHB}$ with coconut and fiber is much darker than the commercial CHB. The texture of both specimens are absolutely rough, they are the same with this property. Both CHB has a dimension of $100 \mathrm{~mm} x$ $400 \mathrm{~mm} \times 800 \mathrm{~mm}$. It is commonly used material for construction purposes such as wall panels and partitions. Moreover, CHB with coconut shell and fiber has a density of $1213.59 \mathrm{~kg} / \mathrm{m}^{3}$ while commercial CHB has a density of 1529 $\mathrm{kg} / \mathrm{m}^{3}$.

Table 1. Physical properties of CHB

\begin{tabular}{c|c|c}
\hline Property & Commercial CHB & $\begin{array}{c}\text { CHB with coconut } \\
\text { shell } \\
\text { and fiber }\end{array}$ \\
\hline Color & Gray & $\begin{array}{c}\text { Dark Gray } \\
\text { Rough }\end{array}$ \\
Texture & $\begin{array}{c}\text { Rough } \\
\text { Size }\end{array}$ & $100 \times 400 \times 800 \mathrm{~mm}$ \\
Density & $1529 \mathrm{~kg} / \mathrm{m}^{3}$ & $100 \times 400 \times 800 \mathrm{~mm}$ \\
$1213.59 \mathrm{~kg} / \mathrm{m}^{3}$
\end{tabular}

Table 2 and figure 2 show the passing percent of coconut shell and fiber according to the size dictated by the hole-size of the sieve, and thus separated into different classifications of sizes [13], [16] [35].

Table 2. Sieve analysis of coconut shells and fibers

\begin{tabular}{c|c|c|c}
\hline Sieve No. & Weight & $\begin{array}{c}\text { Cumulative } \\
\text { weight }\end{array}$ & \% Passing \\
& retained (g) & retained (g) & \\
\hline 1 '” & 0.00 & 0.00 & 100 \\
$3 / 4$, & 0.00 & 0.00 & 100 \\
$1 / 2$, & 863.00 & 863.00 & 157.29 \\
$3 / 8$, & 566.80 & 1249.80 & 29.24 \\
$\# 4$ & 449.00 & 1878.80 & 7.01 \\
$\# 8$ & 54.10 & 1932.90 & 4.34 \\
Pan & 87.60 & 2020.50 & 0.00 \\
\hline
\end{tabular}

\section{Sieve Analysis}

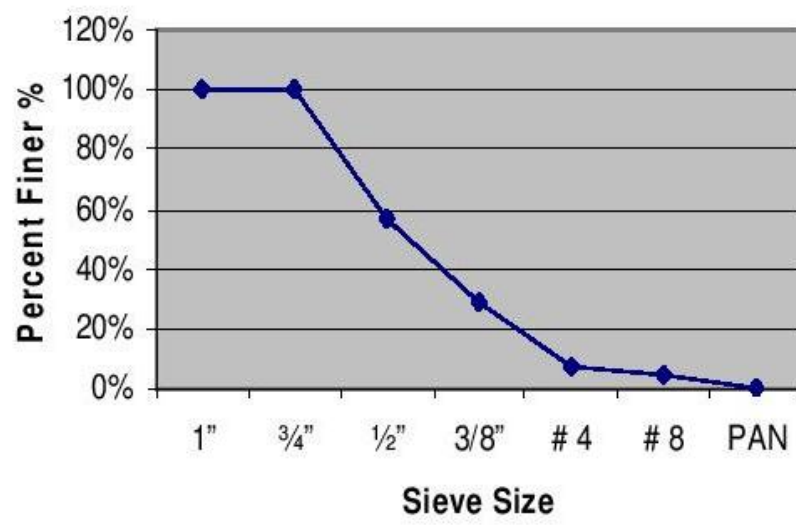

Fig. 2. Sieve analysis of coconut shells and fiber

\subsection{Mechanical Properties of Concrete Hollow Blocks (CHB)}

As shown in table 3 and figure 4, the compressive strength of $\mathrm{CHB}$ w/ coconut shell and fiber in 7 days of age reached a load capacity of $34.42 \mathrm{KN}$ to $43.5 \mathrm{KN}$, and stress capacity of $1.67 \mathrm{Mpa}$ to $2.11 \mathrm{Mpa}$. For 14 days of age reached a load capacity of $48.02 \mathrm{KN}$ to $60.25 \mathrm{KN}$ and a stress capacity of $2.33 \mathrm{MPa}$ to $2.92 \mathrm{MPa}$. For 28 days of age reached a load capacity $65 \mathrm{KN}$ to $84.99 \mathrm{KN}$ and a stress capacity $3.16 \mathrm{MPa}$ to $4.13 \mathrm{MPa}$. This signifies that the number of aging requirements was achieved [14], [15], [34].

As shown in figure 5, the commercial CHB, in 7 days of age reached a load capacity of $11.65 \mathrm{KN}$ to $17.58 \mathrm{KN}$, and stress capacity of $0.57 \mathrm{MPa}$ to $0.8 \mathrm{MPa}$. For 14 days of age reached a load capacity of $14.71 \mathrm{KN}$ to $20.24 \mathrm{KN}$ and a stress capacity of $0.71 \mathrm{MPa}$ to $0.98 \mathrm{MPa}$. For 28 days of age reached a load capacity $25.09 \mathrm{KN}$ to $27.07 \mathrm{KN}$ and a stress capacity $1.22 \mathrm{MPa}$ to $1.31 \mathrm{MPa}$. This signifies that the number of aging requirements was achieved. 


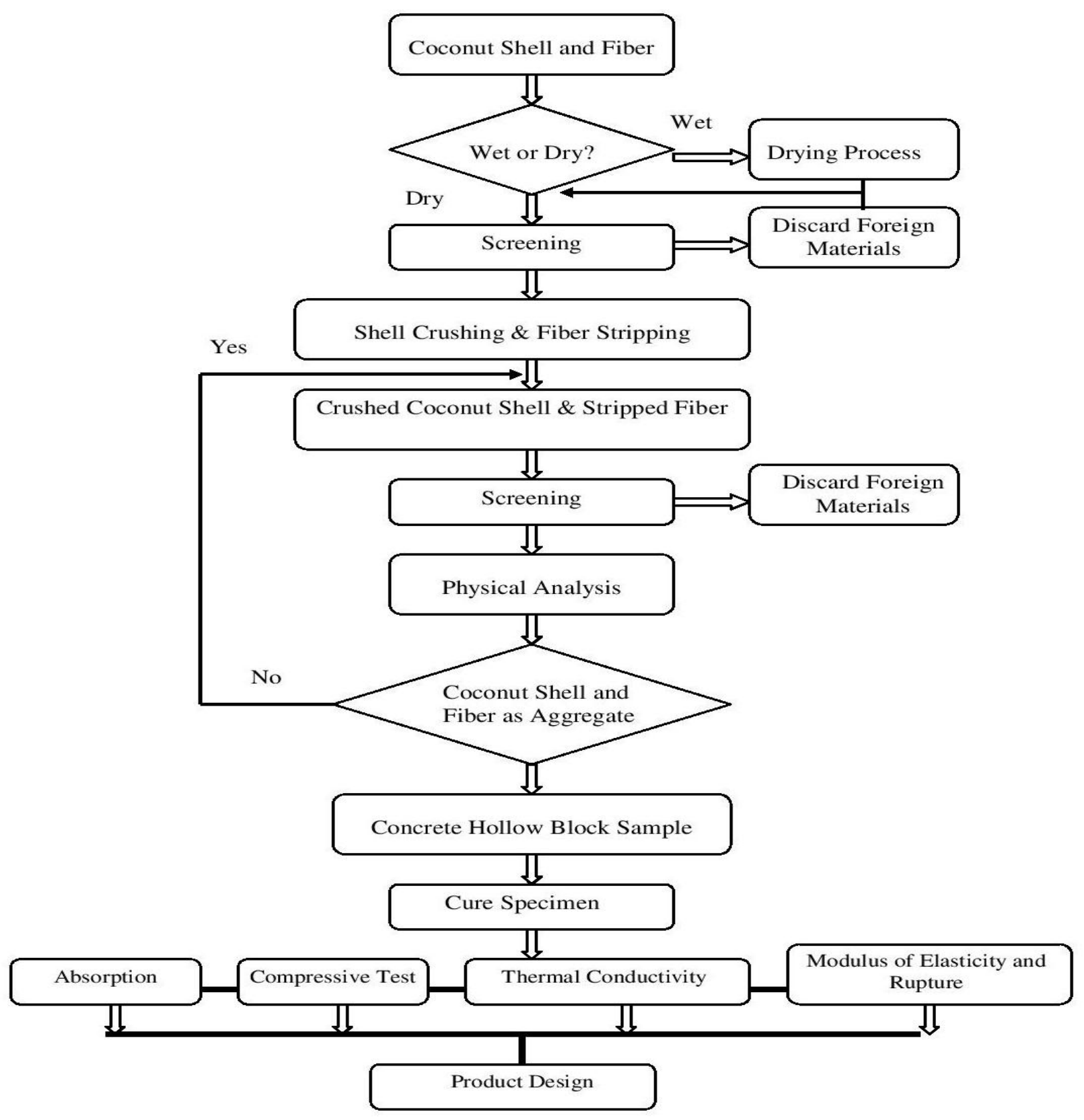

Fig. 3. Project development

Table 3. Compressive strength test of commercial CHB and CHB with coconut shell and fiber

\begin{tabular}{|c|c|c|c|c|c|c|}
\hline \multirow[b]{2}{*}{$\underset{\text { (days) }}{\text { Time }}$} & \multicolumn{3}{|c|}{$\begin{array}{c}\text { Commercial } \\
\text { CHB }\end{array}$} & \multicolumn{3}{|c|}{$\begin{array}{c}\text { CHB with coconut shell } \\
\text { and } \\
\text { fiber }\end{array}$} \\
\hline & Specimen & $\begin{array}{l}\text { Load } \\
(\mathrm{KN})\end{array}$ & $\begin{array}{l}\text { Stress } \\
(\mathrm{MPa})\end{array}$ & Specimen & $\begin{array}{l}\text { Load } \\
(\mathrm{KN})\end{array}$ & $\begin{array}{l}\text { Stress } \\
\text { (MPa) }\end{array}$ \\
\hline \multirow{3}{*}{7} & 1 & 17.58 & 0.8 & 1 & 43.5 & 2.11 \\
\hline & 2 & 11.65 & 0.57 & 2 & 34.42 & 1.67 \\
\hline & 3 & 15.07 & 0.73 & 3 & 37.56 & 1.82 \\
\hline \multirow{3}{*}{14} & 1 & 20.24 & 0.98 & 1 & 48.02 & 2.33 \\
\hline & 2 & 14.71 & 0.71 & 2 & 60.25 & 2.92 \\
\hline & 3 & 14.9 & 0.72 & 3 & 50.74 & 2.46 \\
\hline \multirow{3}{*}{28} & 1 & 27.07 & 1.31 & 1 & 65.00 & 3.16 \\
\hline & 2 & 25.09 & 1.22 & 2 & 75.63 & 3.67 \\
\hline & 3 & 26.09 & 1.27 & 3 & 84.99 & 4.13 \\
\hline
\end{tabular}

Compressive Strength

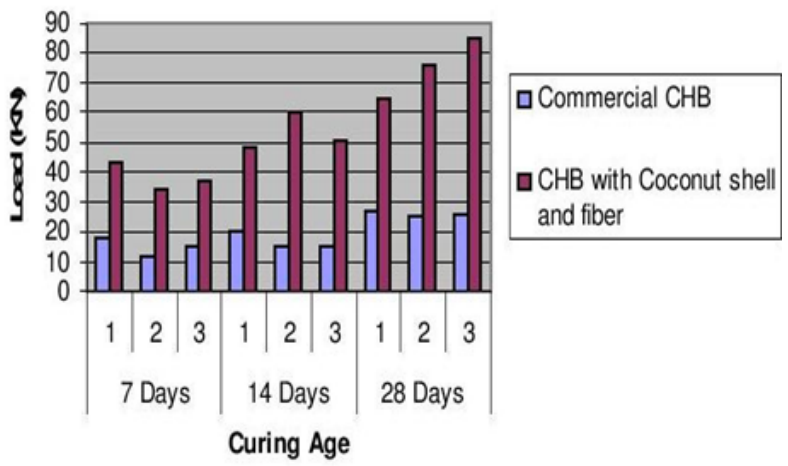

Fig 4. Compressive strength of commercial $\mathrm{CHB}$ and $\mathrm{CHB}$ with coconut shell and fiber $7^{\text {th }}, 14^{\text {th }}$ and $28^{\text {th }}$ days of curing 


\section{Average Load}

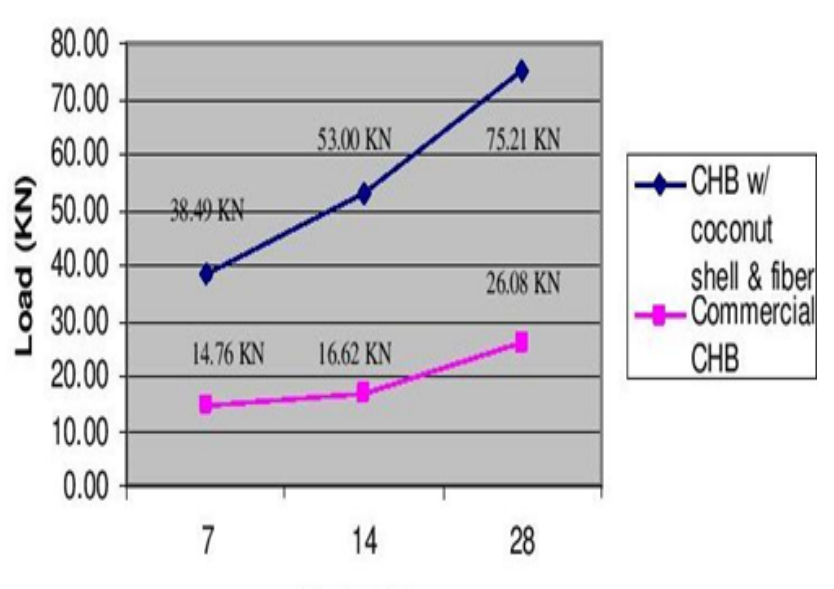

Curing Age

Fig. 5. Average Loads of $\mathrm{CHB}$ w/ coconut \& fiber and commercial CHB after $7^{\text {th }}, 14^{\text {th }}$ and $28^{\text {th }}$ days of curing

Table 4 and figure 6 show that the average modulus of elasticity of CHB w/ coconut shells and fiber for $7^{\text {th }}, 14^{\text {th }}$ and $28^{\text {th }}$ are $1400 \mathrm{MPa}, 1927.5 \mathrm{MPa}$ and $2740 \mathrm{MPa}$ while commercial CHB for $7^{\text {th }}, 14^{\text {th }}$ and $28^{\text {th }}$ days has an average modulus of elasticity of $525 \mathrm{MPa}, 602.5 \mathrm{MPa}$, and $950 \mathrm{MPa}$. Using modulus of elasticity for concrete unit masonry, $\hat{\mathrm{E}}_{\mathrm{m}}=$ $750 \mathrm{f}$ ' $\mathrm{m}$ and must not be greater than $20.5 \mathrm{GPa}$ [12], [19], [36]. Based from the results CHB w/ coconut shell sand fiber has greater modulus of elasticity rather than commercial CHB.

Table 4 and figure 6 show that the average modulus of elasticity of $\mathrm{CHB} \mathrm{w} /$ coconut shells and fiber for $7^{\text {th }}, 14^{\text {th }}$ and $28^{\text {th }}$ are $1400 \mathrm{MPa}, 1927.5 \mathrm{MPa}$ and $2740 \mathrm{MPa}$ while commercial $\mathrm{CHB}$ for $7^{\text {th }}, 14^{\text {th }}$ and $28^{\text {th }}$ days has an average modulus of elasticity of $525 \mathrm{MPa}, 602.5 \mathrm{MPa}$, and $950 \mathrm{MPa}$. Using modulus of elasticity for concrete unit masonry, $\hat{\mathrm{E}}_{\mathrm{m}}=$ $750 f \mathrm{c} \mathrm{m}$ and must not be greater than $20.5 \mathrm{GPa}$ [12], [19], [36]. Based from the results $\mathrm{CHB}$ w/ coconut shell sand fiber has greater modulus of elasticity rather than commercial CHB.

Table 4. Modulus of elasticity of commercial CHB and CHB with coconut shell and fiber

\begin{tabular}{c|c|c|c}
\hline \multirow{2}{*}{$\begin{array}{c}\text { Time } \\
\text { (days) }\end{array}$} & \multicolumn{3}{|c}{ Modulus of Elasticity (MPa) } \\
\cline { 2 - 4 } & Specimen & $\begin{array}{c}\text { Commercial } \\
\text { CHB }\end{array}$ & $\begin{array}{c}\text { CHB with coconut } \\
\text { shell and fiber }\end{array}$ \\
\hline \multirow{3}{*}{7} & 1 & 600.00 & 1582.50 \\
& 2 & 427.50 & 1252.50 \\
& 3 & 547.50 & 1365.50 \\
\multirow{3}{*}{14} & 1 & 735.00 & 1747.50 \\
& 2 & 532.50 & 2190.00 \\
& 3 & 540.00 & 1845.00 \\
28 & 1 & 982.50 & 2370.00 \\
& 2 & 915.00 & 2752.50 \\
& 3 & 952.50 & 3097.50 \\
\hline
\end{tabular}

\section{Modulus of Elasticity}

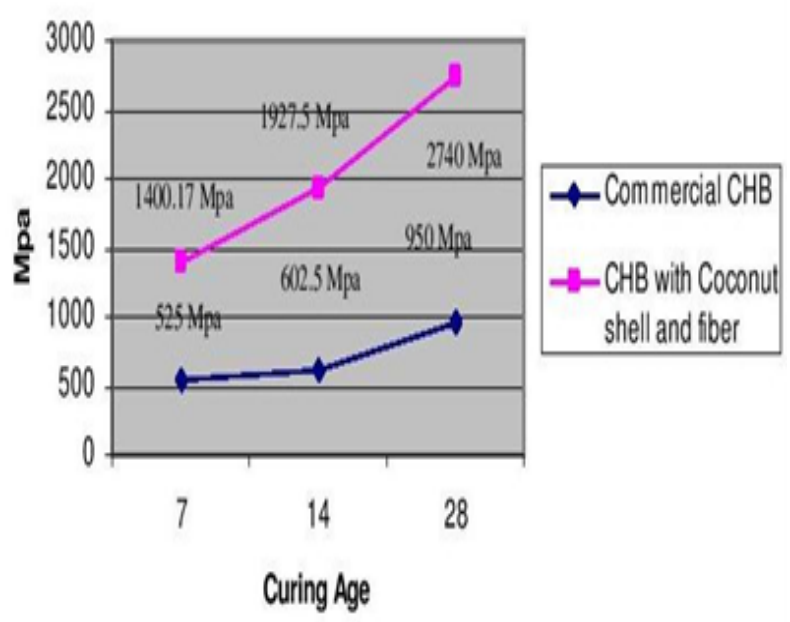

Fig. 6. Average modulus of elasticity after $7^{\text {th }}, 14^{\text {th }}$ and $28^{\text {th }}$ days of curing

Table 5 and figure 7 shows that the average modulus of rupture of $\mathrm{CHB}$ with coconut shell and fiber for 7th, 4th and 28th days are $0.392 \mathrm{MPa}, 0.54 \mathrm{MPa}$ and $0.40 \mathrm{MPa}$.

Table 5. Modulus of rupture of $\mathrm{CHB}$ with coconut shell and fiber

\begin{tabular}{c|c|c}
\hline $\begin{array}{c}\text { Time } \\
\text { (days) }\end{array}$ & Specimen & $\begin{array}{c}\text { CHB with coconut shell and } \\
\text { fiber }\end{array}$ \\
\hline \multirow{3}{*}{7} & 1 & 0.4431 \\
& 2 & 0.3507 \\
& 3 & 0.3822 \\
14 & 1 & 0.4893 \\
& 2 & 0.6132 \\
& 3 & 0.5166 \\
28 & 1 & 0.3733 \\
& 2 & 0.4020 \\
\hline
\end{tabular}

$\mathrm{CHB}$ with Coconut shell and fiber

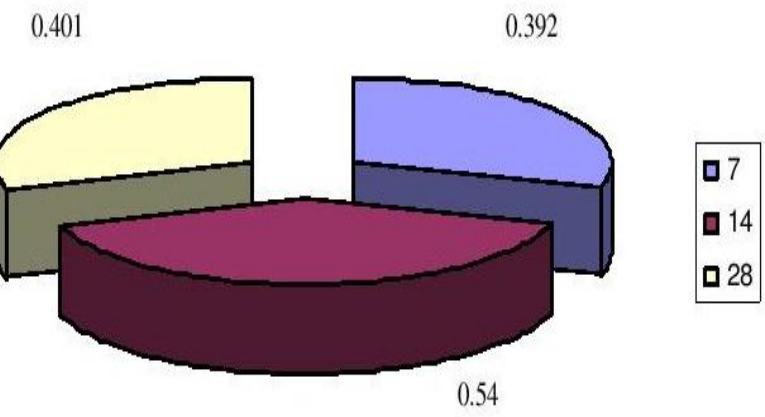

Fig. 7. Average modulus of rupture after 7th, 14th and 28th days of curing

Table 6 shows that CHB with coconut shell and fiber have lesser moisture content and water absorption than the commercial CHB. 
Table 6. Moisture content of concrete hollow blocks

\begin{tabular}{l|c|c}
\hline \multicolumn{1}{c|}{ Specimen } & $\begin{array}{c}\text { Commercial } \\
\text { of CHB }\end{array}$ & $\begin{array}{c}\text { CHB with Coconut } \\
\text { shell and fiber }\end{array}$ \\
\hline $\begin{array}{l}\text { Weight (Kg) } \\
\begin{array}{l}\text { Oven dry weight } \\
\text { (Kg) }\end{array}\end{array}$ & 5.2 & 7.8 \\
$\begin{array}{l}\text { Saturated weight } \\
\text { (Kg) }\end{array}$ & 5.0 & 7.6 \\
\% Moisture content & 8.0 & 7.8 \\
\% Water absorption & 4.0 & 5.41 \\
\hline
\end{tabular}

Table 7 shows that $\mathrm{CHB}$ with coconut shell and fiber can resist freezing gained a large value of load. In cold temperature, $\mathrm{CHB}$ with coconut shell and fiber has a load capacity of $96.69 \mathrm{KN}$ and stress capacity of $4.69 \mathrm{MPa}$

Table 7. Thermal conductivity at cold temperature

\begin{tabular}{c|c|c}
\hline Specimen & $\begin{array}{c}\text { Commercial } \\
\text { CHB }\end{array}$ & $\begin{array}{c}\text { CHB with Coconut } \\
\text { shell and fiber }\end{array}$ \\
\hline Weight $(\mathrm{Kg})$ & 12.4 & 10.6 \\
Load $(\mathrm{KN})$ & 12.87 & 96.69 \\
Stress (MPa) & 0.62 & 4.69 \\
\hline
\end{tabular}

Table 8 shows that even in high temperature condition, $\mathrm{CHB}$ with coconut shell and fiber can resist. It was subjected to compressive test to determine if the strength will change [17], [18]. In warm temperature, CHB with coconut shell and fiber has a load capacity of $50.47 \mathrm{KN}$ and stress capacity of $2.97 \mathrm{MPa}$

Table 8. Thermal conductivity at warm temperature

\begin{tabular}{c|c|c|c}
\hline Specimen & Weight (Kg) & Load (KN) & Stress (MPa) \\
\hline 1 & 6.8 & 50.47 & 2.97 \\
\hline 2 & 9.4 & 59.98 & 2.97 \\
\hline
\end{tabular}

Table 9 shows that the specimens are subjected to a high degree of temperature for a certain period of time. It was subjected to compressive test to determine if the strength will change. Data's gathered shows that $\mathrm{CHB}$ with coconut shell and fiber can resist in fire. This means that $\mathrm{CHB}$ with coconut shells and fiber can resist in high degree of temperature [19]. [37]. [40]. The results at 28th days attained an average load capacity of $64.15 \mathrm{KN}$ and $3.175 \mathrm{MPa}$ for average stress.

Table 9. Fire resistances of CHB with coconut shell and fiber.

\begin{tabular}{c|c|c|c}
\hline Specimen & Weight (Kg) & Load (KN) & Stress (MPa) \\
\hline 1 & 9.8 & 68.32 & 3.38 \\
2 & 9.4 & 59.98 & 2.97 \\
\hline
\end{tabular}

aggregate

\begin{tabular}{|c|c|}
\hline Good Indicators & Significance \\
\hline $\begin{array}{l}\text { 1. Particles shape and } \\
\text { Texture. }\end{array}$ & $\begin{array}{l}\text { Affects workability of fresh } \\
\text { concrete. }\end{array}$ \\
\hline $\begin{array}{l}\text { 2. Resistance to } \\
\text { crushing. }\end{array}$ & $\begin{array}{l}\text { In high strength concrete, } \\
\text { aggregate is low in crushing } \\
\text { value. This will not give high } \\
\text { strength even though cement } \\
\text { strength is higher. }\end{array}$ \\
\hline $\begin{array}{l}\text { 3. Absorption and } \\
\text { surface moisture }\end{array}$ & $\begin{array}{l}\text { Affects the mix proportions and } \\
\text { control water content to maintain } \\
\text { water-cement ratio }\end{array}$ \\
\hline 4. Grading & $\begin{array}{l}\text { Economizes cement content and } \\
\text { improves workability. }\end{array}$ \\
\hline $\begin{array}{l}\text { 5. Resistance to } \\
\text { freezing and heating. }\end{array}$ & $\begin{array}{l}\text { Where frost action deteriorates } \\
\text { concrete due to alternate freezing } \\
\text { and heating. }\end{array}$ \\
\hline 6. Lightweight & Reduce weight of structure. \\
\hline
\end{tabular}
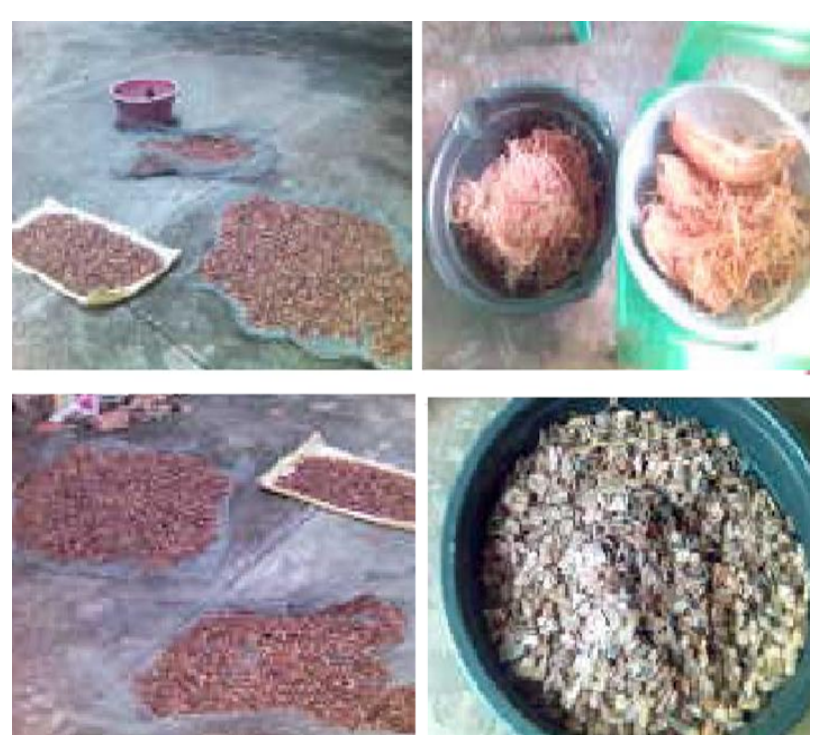

Fig 8. Preparation of $\mathrm{CHB}$ with coconut shell and fiber
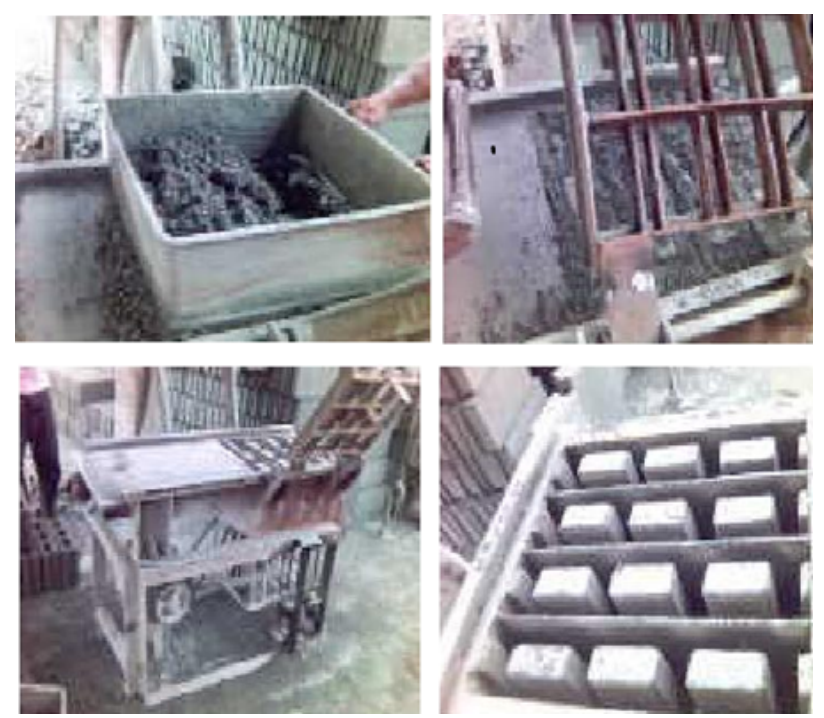

Fig. 9. Molding of CHB with coconut shell and fiber

Table 10. Good indicators of coconut shell and fiber as 

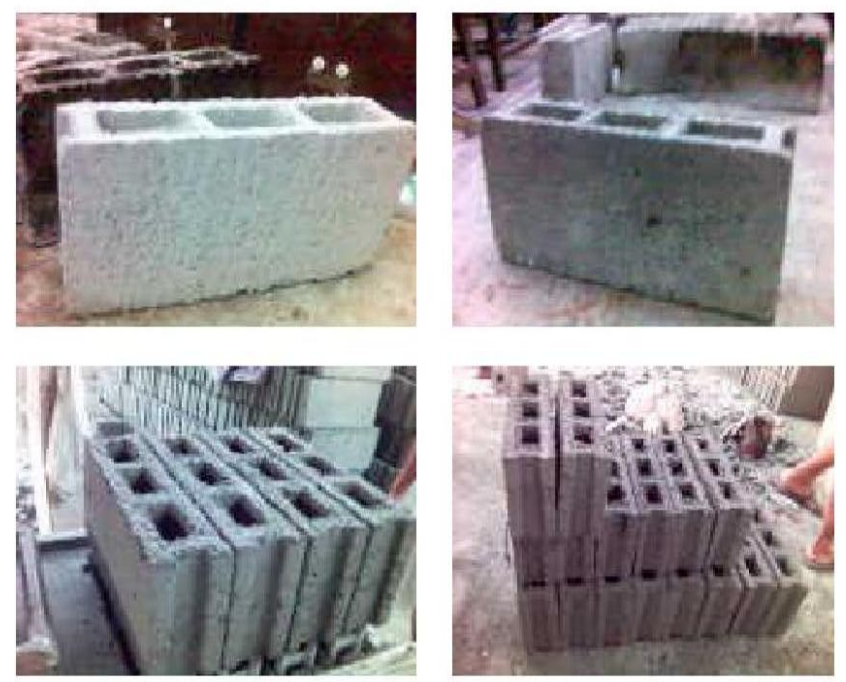

Fig. 10. Commercial $\mathrm{CHB}$ and $\mathrm{CHB}$ with coconut shell and fiber

\section{Conclusions}

This early study found that addition of coconut shell as partial aggregate replacement reduces the concrete workability owing to its shape and rougher texture. However, it is interesting to note that replacement of natural coarse aggregate by coconut shell resulted in the increase of compressive strength compared to conventional concrete mixture. Nevertheless, integration of too much of coconut shell produces harsher mix which causes difficulties to produce dense concrete thus disrupts the strength performance.

\section{References}

1. Mamlouk, M.S. and Zaniewski, J.P., Materials for Civil and Construction Engineers, National Bookstore: Manila, pp. 305-311, 2006.

2. Meyer, C., Recycled Glass: Waste Material To Valuable Resource, Construction Materials and Technology, Vol 1, Jan 2001, pp. 1214.

3. Adams, J.T., The Complete Concrete, Masonry and Brick Handbook,"New York: AR Co., pp. 211-213, 1979.

4. Lee, J., Utilization of Solid Wastes as Aggregates in Concrete, Journal of Waste Glass and Rubber Particles, Vol. 3, pp. 123-134, 2003.

5. Mamlouk, M. S. and Zaniewski, J.P., Laboratory Manual for Masonry, National Bookstore: Manila, pp. 487-523, 2006.

6. J. Remigio, "Coal Bottom Ash as Partial Replacement of Fine Aggregates in Hollow Load-Bearing Concrete Masonry Units," Undergraduate Thesis, College of Engineering, Dela Salle University, Manila, 2003.

7. Somayaji, S., Civil Engineering Materials, National Bookstore: Manila, pp. 47-53, 2001.

8. National Solid Waste Management Commission, Alter-native Technologies Part 2: Recycled Materials, 2003, pp. 123-145

9. Gambar, M.L., Concrete Technology, John Willey \& Sons Inc., pp. 220-223, 2011.

10. Handoo M., and Mahajan, J., Civil Engineering Materials, $1^{\text {st }}$ ed. Quezon City: R.M. Garcia Publishing House, pp.156-165, 1992.

11. Handoo M., Civil Engineering Materials. CRE Press, pp. 109-118, 1998

12. National Structural Code of the Philippines Section 708.2.4.6.6 Modulus of Rupture for Partially Grouted Hollow Unit Masonry, National Bookstore: Manila, pp. 411-440, 1992

13. National Structural Code of the Philippines S 706.2. 12.1 Modulus of Elasticity of Masonry, National Bookstore: Manila, pp. 214-220, 1992.

14. ASTM C 136 Standard Test Method for Sieve Analysis of Coarse Aggregate, pp. 567-580, 2011.

15. ASTM C 172 Standard Test Method for Slump of Freshly Mixed Portland Cement Concrete, pp. 700-720, 2011

16. ASTM C 173 Standard Test Method for Compressive Strength, pp. 723-734, 2011.

17. ASTM E 119 Standard Test Method for Fire Resistance, pp. 1111$1213,2011$.

18. ASTM C 177 Standard Test Method for Thermal Conductivity, pp. 834-857, 2011.

19. Allen, J., Fundamentals of Building Construction: Materials and Methods, Wiley and Sons Inc., pp. 234-237, 2008.

20. Babel, Sandhya, and Tonni Agustiono Kurniawan. Cr (VI) Removal from Synthetic Wastewater using Coconut Shell Charcoal and Commercial Activated Carbon modified with Oxidizing Agents and/or Chitosan, Chemosphere 54, No. 7, 2004, pp. 951-967.

21. Hu, Zhonghua, and M. P. Srinivasan, Preparation of HighSurface-Area Activated carbons from Coconut Shell. Microporous and Mesoporous Materials 27, No. 1, 1999, pp. 11-18.

22. Laine, Jorge, and Simon Yunes, Effect of the Preparation Method on the Pore Size Distribution of Activated Carbon from Coconut Shell, Carbon 30, No. 4, 1992, pp. 601-604.

23. Amuda, O. S., AAm Giwa, and I. A. Bello, Removal of Heavy Metal from Industrial Wastewater using Modified Activated Coconut Shell Carbon, Biochemical Engineering Journal 36, No. 2, 2007, pp. 174-181.

24. Pino, Gabriela Huamán, Luciana Maria Souza de Mesquita, Mauricio Leonardo Torem, and Gustavo Adolfo Saavedra Pinto, Biosorption of Cadmium by Green Coconut Shell Powder, Minerals Engineering 19, No. 5, 2006, pp. 380-387.

25. Tsai, W. T., M. K. Lee, and Y. M. Chang, Fast Pyrolysis of Rice Straw, Sugarcane Bagasse and Coconut Shell in an InductionHeating Reactor. Journal of Analytical and Applied Pyrolysis 76, No. 1, 2006, pp. 230-237.

26. Daud, Wan Mohd Ashri Wan, and Wan Shabuddin Wan Ali, Comparison on Pore Development of Activated Carbon Produced from Palm Shell and Coconut Shell, Bioresource Technology 93, No. 1,2004, pp. 63-69.

27. Kirubakaran, C. John, K. Krishnaiah, and S. K. Seshadri, Experimental Study of the Production of Activated Carbon from Coconut Shells in a Fluidized Bed Reactor, Industrial \& Engineering Chemistry Research 30, No. 11, 1991, pp. 24112416.

28. Azevedo, Diana, J. Araujo, Moisés Bastos-Neto, A. Eurico B. Torres, Emerson F. Jaguaribe, and Celio L. Cavalcante, Microporous Activated Carbon Prepared from Coconut Shells using Chemical Activation with Zinc Chloride, Microporous and Mesoporous Materials 100, No. 1,2007,pp. 361-364.

29. Tsamba, Alberto J., Weihong Yang, and Wlodzimierz Blasiak, Pyrolysis Characteristics and Global Kinetics of Coconut and Cashew Nut Shells, Fuel Processing Technology 87, No. 6, 2006, pp. 523-530.

30. Li, Wei, Kunbin Yang, Jinhui Peng, Libo Zhang, Shenghui Guo, and Hongying Xia, Effects of Carbonization Temperatures on Characteristics of Porosity in Coconut Shell Chars and Activated Carbons derived from Carbonized Coconut Shell Chars, Industrial Crops and Products 28, No. 2, 2008, pp. 190-198

31. Yalcin, Mustafa, and Ali Ihsan Arol, Gold Cyanide Adsorption Characteristics of Activated Carbon of Non-Coconut Shell Origin, Hydrometallurgy 63, No. 2, 2002, pp. 201-206.

32. Tam, Man S., and Michael Jerry Antal Jr, Preparation of Activated Carbons from Macadamia Nut Shell and Coconut Shell by Air Activation, Industrial \& Engineering Chemistry Research 38, No. 11, 1999, pp. 4268-4276. 
33. Ganiron, T. U. Jr, Concrete Debris as Alternative Fine Aggregate for Architectural Finishing Mortar, Architecture Research 2, No. 5, 2012, pp. 111-114.

34. Hu, Zhonghua, M. P. Srinivasan, and Yaming Ni, Novel Activation Process for preparing Highly Microporous and Mesoporous Activated Carbons, Carbon 39.6, 2001, pp. 877-886.

35. Pollard, S. J. T., G. D. Fowler, C. J. Sollars, and R. Perry, LowCost Adsorbents for Waste and Wastewater Treatment: A Review, Science of the Total Environment 116, No. 1, 1992, pp 31-52.

36. Adinata, Donni, Wan Mohd Ashri Wan Daud, and Mohd Kheireddine Aroua, Preparation and Characterization of Activated Carbon from Palm Shell by Chemical Activation, Bioresource Technology 98, No. 1, 2007, pp. 145-149.
37. Ganiron, T. U. Jr, Recycled Window Glass for Non-Load Bearing Walls, International Journal of Innovation, Management and Technology, Vol. 3, No. 6, December 2012, pp. 725-730.

38. Fagbemi, L., L. Khezami, and R. Capart, Pyrolysis Products from Different Biomasses: Application to the Thermal Cracking of Tar, Applied Energy 69, No. 4, 2001, pp. 293-306.

39. Rahman, I. A., and B. Saad, Utilization of Guava Seeds as a Source of Activated Carbon for Removal of Methylene Blue from Aqueous Solution, Malaysian Journal of Chemistry 5, No. 1, 2003, pp. 8-14

40. Murali, T. P., et al.,"Friction and Wear Behaviour of Aluminium Alloy Coconut Shell Char Particulate Composites, Wear 80.2, 1982, pp. 149-158. 